\title{
Developing Cosmopolitan Communicative Competence Through Online Transnational Encounters
}

\section{Zhiwei Wu E Xinqiang Li}

This article reports on a study examining the extent to which pedagogical activities can affect students' cosmopolitan communicative competence (CCC) through online transnational encounters. A total of 58 students from a Hong Kong university and 25 students from an American university were divided into 25 transnational groups. They communicated with each other through Google Docs, sharing culturally rich texts, exchanging views on these texts, and discussing rhetorical and cultural preferences/differences. After analyzing 90,000-word communication transcripts, we found that most of the students demonstrated and developed their cosmopolitan dispositions, skills, and knowledge. Based on these findings, we discuss how the activity contributed to the students' CCC by addressing four dialectical relations: historicity-modernity, text-context, self-other, and universality-particularity. The participants were challenged to make seemingly culturally irrelevant texts relevant to the transnational peers by moving the (ancient) texts across time scales and sociocultural contexts. The online communication based on the culturally (ir)relevant texts was a valuable site for the learners to enhance understanding about self and other, and examine the intricacies between universal and particular norms, values, and beliefs. The four dialectical relations can function as a set of heuristics for practitioners and researchers to reframe digital English Language Teaching (ELT) practices from the perspective of cosmopolitanism.

Cet article est un compte rendu d'une étude menée pour permettre de jeter un regard sur la mesure dans laquelle les activités pédagogiques peuvent affecter la compétence de communication cosmopolite (CCC) des étudiantes et étudiants grâce à des rencontres internationales en ligne. Un groupe d'étudiantes et étudiants dont 58 provenaient d'une université hongkongaise et 25, d'une université américaine, a été subdivisé en 25 groupes transnationaux. Ceux-ci ont communiqué entre eux dans Google Docs pour partager des textes à forte teneur culturelle, échanger des vues sur leurs textes et discuter de préférences/différences en matière de contenu stylistique et de culture. Après avoir analysé des transcriptions d'une longueur globale de 90000 mots, nous avons été à même de constater que la majorité des étudiantes et étudiants possédaient et développaient des dispositions, des compétences et des connaissances cosmopolites. Sur la base de ces constatations, nous avons cherché à voir ce que l'activité avait apporté à la CCC des étudiantes et étudiants en appliquant quatre relations dialectiques: historicité-modernité, texte-contexte, soi-autre et universalité-particularité. Les 
participantes et participants ont été mis au défi de prendre des textes en apparence dépourvus de pertinence culturelle et de les rendre pertinents à des pairs transnationaux en transposant les textes (anciens) sur des échelles temporelles et à travers divers contextes socioculturels. La communication en ligne basée sur des textes (non)pertinents a procuré un point de rencontre important pour permettre aux apprenantes et apprenants d'approfondir leur compréhension de soi et de l'autre et de se sensibiliser à la subtilité des rapports qui existent entre les normes, les valeurs et les croyances universelles et particulières. Les quatre relations dialectiques peuvent fonctionner comme un jeu d'heuristiques au niveau de l'enseignement et des recherches en permettant de recadrer les pratiques numériques d'enseignement de l'anglais (ELT) sous l'angle du cosmopolitisme.

KEYWORDS: cosmopolitanism, cosmopolitan communicative competence, digital, transnational, ELT

\section{Introduction}

As the world is increasingly interdependent and diverse, cultivating the abilities to communicate across differences has become one of the important goals of language teaching and learning. In 2007, the Modern Language Association (MLA) Ad Hoc Committee on Foreign Languages urged English Language Teaching (ELT) practitioners to develop learners' "translingual and transcultural competence" (MLA, p. 237). Similar suggestions have been made by organizations worldwide, such as UNESCO (2014) and the Council of Europe (2018). As such, over the past two decades, multifarious pedagogical endeavours have been undertaken to engage language learners in intercultural encounters through which learners develop their abilities and skills to cross linguistic and cultural borders. One such endeavour is technology-mediated transnational writing education (Wu, 2018a). Enabled by technological affordances and increased connectivity, learners with various backgrounds share their understandings about writing traditions and styles in an online space unbounded by geographical, linguistic, or cultural borders. The fluid, cosmopolitan nature of digital practices makes the online space a meaningful site for learners to build up a globalizing meaning-making repertoire (You, 2016). Although technology-mediated transnational writing education has great potential to enhance learners' sensitivity to cultures, existing pedagogical designs have tended to focus on developing learners' knowledge about discrete, nation-based categories of cultures (see $\mathrm{Wu}, 2018$ a for an overview). Heeding Walsh-Marr's (2011) caution that ELT practitioners should not reduce cultural teaching to a laundry list of "cultural do's and don'ts" (p. 118), this study adopts a cosmopolitan approach to online transnational encounters, whereby learners are challenged to explore and experience the 
fluid, dynamic nature of cultures. In the following sections, we first explain a pivotal concept that frames our pedagogical design, that is, cosmopolitan communicative competence (CCC) and compare it with Byram's $(1997,2008)$ intercultural communicative competence. After that, we describe the rationale, procedure, and technical setup of our pedagogical activity. Based on the communication transcripts, we elucidate how the online transnational encounter developed the participants' CCC by addressing four dialectical relations: historicity-modernity, text-context, self-other, and universality-particularity. We conclude with implications for designing digital ELT activities that tap transnational semiotic resources to develop learners' abilities to communicate in and across communities (You, 2016).

\section{Cosmopolitan Communicative Competence}

Byram's $(1997,2008)$ seminal model conceptualizes intercultural communicative competence (ICC) into three dimensions (i.e., attitudes, knowledge, and skills) and five associated savoirs, including (a) intercultural attitudes (savoir être), (b) intercultural knowledge (savoirs), (c) skills of interpreting and relating (savoir comprendre), (d) skills of discovery and interaction (savoir apprendre/faire), and (e) critical cultural awareness (savoir s'engager). Whereas the model provides a useful framework for ELT practitioners to set goals and scopes for training intercultural communicators, one vexing problem, as suggested by Risager (2007), is that the model implies a stable, nation-based view of culture, unwittingly disregarding transnational communication between people with complex, multifarious backgrounds. In Wilkinson's (2012) words, "'Intercultural' connotes exchange 'between' (inter) at least two cultures and therefore suggests that these cultures exist as definable and more or less bounded entities, often (but not always) locatable within politically determined nation-states" (p. 300, emphasis in original). The monolithic view of culture as a discrete entity has been called into question by a growing body of research, which foregrounds the fuzzy, dynamic, and contested nature of culture (Galante, 2014; $\mathrm{Wu}, 2018 \mathrm{a}, 2018 \mathrm{~b}$ ). A corollary of this is a prominent focus on enhancing learners' critical awareness of and reflection on their language practices in multilingual and multicultural spaces (Kapoyannis, 2019; You, 2016). The nation-based categorization of culture is less relevant in online transnational communication because "super-diversity" (after Vertovec, 2007) is exacerbated by increased connectivity and time-space compression. In this super-diverse context, there is a need for us to extend Byram's model in the direction of cosmopolitanism (Risager, 2007).

Cosmopolitanism can be traced back to ancient Greek, kosmopolites, meaning "citizen of the world." Cosmopolitanism posits that we are all human beings and owe our allegiance to a global humanity. As such, one shall not be bounded by the community or category one is born into, but develop multiple affiliations with social groups that transcend conventional, artificial 
categories (i.e., nation, culture, ethnicity). Going beyond the particularities and seeking universality has been one of the defining features of cosmopolitanism (Beck, 2006). However, as Mihelj et al. (2011) aptly point out, cosmopolitanism should not be viewed as "an accomplished state of universalism" but "a permanent quest for universalism," "not a negation of the particular, but a constant engagement with it" (p. 615). Appiah (2005) nicely sums up cosmopolitanism as "universality plus difference" (p. 151). In light of this, it is useful to frame ELT digital practices from the perspective of cosmopolitanism as an increasing number of teachers and learners are constantly required to communicate across differences in a fluid, super-diverse third space. You (2016) reported on an asynchronous transnational writing activity involving graduate instructors (postgraduate students teaching "first-year writing") from the United States and EAL (English as an additional language) students from China. Through the online communication, the graduate instructors developed a more nuanced understanding about the fluidity of readership, pluralities of genre conventions, and linguistic repertoires conditioned by sociocultural factors. Importantly, the transnational experience prompted the instructors to reflect on cultural issues such as the extent to which one could "be a cultural relativist and respect [global others'] opinions" (You, 2016, p. 212). Building on You's (2016) contention that a cosmopolitan perspective is needed in ELT, we propose CCC as a construct pertinent to ELT digital practices.

We adapt Byram's $(1997,2008)$ tripartite framework (i.e., attitudes, skills, and knowledge) by replacing the attitudes component with dispositions, which are more aligned with the appeal to ethos in the literature about cosmopolitan English (Wu, 2018a; You, 2016). With this adaptation, we conceptualize CCC into three aspects: dispositions, skills, and knowledge. First, dispositions are the ethical dimension of CCC. As we owe our allegiance to a global humanity, we need to take open, curious, and respectful stances in our interactions with global others. This means that we are obligated to interrogate any othering presumption and demonstrate our willingness to listen to, know, and engage global others. Second, skills are the strategic dimension of CCC. Traditionally, ICC is heavily predicated on language proficiency. A number of earlier studies predominantly focused on how online intercultural encounters enabled learners to develop knowledge about Standard English in terms of lexis, syntax (Edasawa \& Kabata, 2007), pragmatics (Belz \& Vyatkina, 2005), and genres (Connor et al., 1997). In other words, Standard English (including linguistic and cultural "accuracy") was the preferred, prioritized learning outcome. In cosmopolitan encounters, however, individuals draw on all available meaning-making resources (e.g., codes, styles, modalities, artifacts) to facilitate engagements with global or translocal others (Canagarajah, 2018). As such, we need to be cognizant of meaning-making resources afforded by and distributed in the communication medium, and then strategically act upon these affordances to communicate across differences. 
Finally, knowledge is the epistemic dimension of CCC. As explained previously, the pursuit of universality requires constant engagement with the particular. In this sense, CCC not only requires us to develop knowledge about global others, but also relativize knowledge about ourselves (Delanty, 2009). That is, the knowledge component of CCC is not an essentialist list of facts, beliefs, or generalizations about cultures that can be acquired or compared without complication. Cultural knowledge should not be static, context-free entities, but dynamic, value-laden processes. When we view knowledge as a verb instead of a noun (Street, 1993), we are poised to develop a nuanced, sophisticated understanding about "universality plus difference." In the following sections, we report and reflect on a pedagogical activity we conducted to enhance language learners' CCC through an online transnational project. We use CCC as a lens to measure and make sense of learners' performances in their encounters with global others.

\section{The Study}

\section{Context and Participants}

This study involved 58 EAL students enrolled in a course called Bilingualism at a public university in Hong Kong and 25 students enrolled in a course called First-year Writing at a public university in the United States. They were divided into 25 groups with one American student working with two or three Hong Kong students. The transnational English writing project was conducted in two stages: preparation and exchange. In the preparation stage, we tapped into the power of literature as a site of rich cultural resources that helped learners construct an imagined cultural world (Kramsch \& Kramsch, 2000; Ros i Solé, 2013). Specifically, the Hong Kong students were asked to choose an ancient Chinese story that manifested a Chinese cultural concept. Then, they adapted the stories into English and explained the underlying concepts in a 150-word analytical prose. They were explicitly told to imagine the intended audience (i.e., the American students) when they adapted and explained the story. In the meantime, the American students were asked to select a piece of English writing (such as a poem, a story, a song, etc.) to share with the Hong Kong students. They also explained their choice and the cultural meanings of the selected piece. In the exchange stage, we expected the imagined and real cultural worlds would intersect and even clash, leading to what Kostogriz (2005) called the production of "thirdness" - creating "new texts, meanings, and identities" when selfhood meets otherhood (p. 198). As instructed, the students worked in small groups and posted their stories and explanations in Google doc files. They exchanged opinions about the writing pieces selected by their peers. Building on this, they discussed the issues of writing traditions, language styles, and cultural perceptions. Two lists of question prompts were offered to the students as topic guides, and they could also explore topics of their interests (see the appendix). The online exchange 
lasted for 10 days and was conducted outside of class. The project accounted for $15 \%$ of the course grade for the Hong Kong students and $10 \%$ for the American students. The students' participation was assessed based on two quantitative measures (i.e., word count and post count), and two qualitative measures (i.e., asking specific questions and providing relevant answers).

\section{Data Collection and Analysis}

At the end of the online exchange, the 25 Google docs were collected. The 25 documents combined produced approximately 90,000 words of communication. We treated the communication transcripts as the observable behaviours indexing the participants' CCC, because behaviours are indicators of people's understandings about cultures and abilities to act across cultures (Byram, 2012). In common with qualitative research traditions (Friedman, 2012), our analysis was conducted in four steps. In the first step, we read the communication transcripts without any presumption so that we understood the entire picture of the interaction in each group. In the second step, we conducted thematic analysis (Richards, 2003) and marked up all the textual segments that reflected the participants' CCC. We used the tripartite framework and grouped these segments into three broad categories: dispositions, skills, and knowledge. In the third step, we examined "the data for emergent patterns and themes" (Mackey \& Gass, 2005, p. 241) by recursively attending to the marked-up segments. For example, we examined the instances indexing the participants' dispositions and grouped their expressed desires to travel around the world and to learn multiple languages into a theme of "spirit of openness." Following this procedure, we identified two themes in the dispositions dimension, four in the skills dimension, and two in knowledge (see Table 1 for detail). In the final step, we read the transcript in its entirety once again, and made sure that "no new themes come out of the analysis," thus, achieving saturation in data analysis and representation (Baralt, 2012, p. 234).

\section{Results}

Table 1 summarizes the themes emergent from the participants' CCC performance in the online interaction. In the following subsections, extracts of transcripts will be cited to exemplify how cosmopolitan dispositions, skills, and knowledge were demonstrated and developed by the participants in the online transnational encounter. Names provided after the extracts are all pseudonyms. For the ease of identification, the Hong Kong students' names are replaced by pseudonyms with an initial K, and the American students with an initial A. 
Table 1

Components and Themes of CCC

\begin{tabular}{ll}
\hline CCC Component & Theme \\
\hline Dispositions & Spirit of openness \\
& Spirit of inquiry \\
\hline Skills & Identity expression \\
& Audience design \\
& Translingual practices \\
& Unsettling essentialism \\
\hline Knowledge & Knowledge about universalism \\
& Engagement with particularism \\
\hline
\end{tabular}

Note. CCC $=$ Cosmopolitan Communicative Competence.

Cosmopolitan Dispositions: Ethos Appeal

Spirit of Openness

The spirit of openness is a cosmopolitan disposition that reminds people to keep an open mind about the world and humanity, instead of navel-gazing through their own cultural/local frame. In the interaction, a vast majority of participants usually expressed their desires to experience different cultures by travelling abroad: "I have never been to America but I really want to, if there is a chance, as visiting other countries is a great opportunity to learn and experience new cultures which are totally different [from] mine" (Ken, Group 8); and "I would love to visit Hong Kong or Tokyo because the city life amazes me! I want to try new food, go shopping, and experience the vibrant nightlife there!" (Amy, Group 8). They also professed their strong desire to learn additional languages, as Kate (Group 2) wrote in her post: "I will never stop learning an entirely new language, because the more languages we learn, the bigger world we [are] aware [of]."

The spirit of openness engendered respect toward others, regardless of their language or ethnic backgrounds. For example, when Alice (Group 23) and her peers discussed the issue of accented English, she highlighted the importance of respecting people's cultural backgrounds and upholding the legitimacy of different English styles:

I am accustomed to hearing accents and tones in English, because throughout my life, I have been exposed to people from different countries who speak English as well. I see nothing wrong with this and I don't find it disturbing at all! I think that it is absurd to assume that every person who speaks English will speak exactly the way I do, because that completely ignores the person's cultural background and our own differences in upbringing. 
In a similar case, Kevin (Group 14) and his peers were prompted to discuss the necessity of treating everyone equally. They noted,

Due to the history of Hong Kong, it is usual for us to see cultural integration. There are also many ethnic minorities living in Hong Kong. Thus, we are taught to treat everyone equally and we should never judge others solely based on their ethnicity.

\section{Spirit of Inquiry}

The purpose of the transnational English writing project, and by extension many other similar online cultural encounters, is not to take a one-off cultural snapshot. Rather, we expect the projects to have a longer term impact on our participants, piquing their interests to embark on a journey of inquiry. To us, willingness to find out more about global others outside the project time frame or scope is one of the important instantiations of cosmopolitan disposition. As it turned out, many participants articulated their interests in knowing more about the others' culture and language. Some typical extracts include,

I would love to learn or study another language such as Chinese and see how the culture has evolved its styles and everything we have talked about. (Aron, Group 5)

Before this project, to my knowledge, I had never read or been told a Chinese story. However, after reading the story that your group has provided, I am now interested in exploring more Chinese stories, as I realize they are not only significant, but the stories help you in your everyday life with their messages. (Alan, Group 12)

I'm really interested in the book you mentioned in your previous post! ... After reading your brief introduction of this book, I did some researches about this book and read its synopsis ... I really long for reading this book by myself and thank you very much to recommend this book to us ... (Kitty, Group 7)

\section{Cosmopolitan Skills: Discursive Strategies}

\section{Identity Expressions}

Although the project seemed to revolve around Chinese and American cultures, most participants were agentive in bringing out their cosmopolitan identities to facilitate the interaction. For example, when responding to a story about the popularity of basketball in America, Kwan (Group 15), a Malaysian student studying in Hong Kong, explained how badminton was widely popular in her home country:

Lee Chong Wei who was ranked first as a badminton single player worldwide in the past few years is a Malaysian. Since he won several 
international competitions, the popularity of badminton rocketed and became a hobby or a culture among Malaysians.

In the ensuing interaction, Kwan professed her cosmopolitan identity when the American student asked whether she watched English movies and listened to English songs:

As for English movies, I like to watch blockbuster movies at the cinemas back in Malaysia. Because of the expensive cinema tickets in Hong Kong, I rarely watch movies here. However, I watch movies online when I have free time ... A part from that, I listen to songs in 3 different languages (Chinese, English, and Korean) almost every day.

During the interaction, some participants discussed issues of language contact and interference and evoked their diverse identities to address the issues. For example, when discussing the influence of the second language on the first language, Alan recounted his lived experience of learning multiple languages:

Other than English I speak Arabic and Chaldean. Although Arabic is my native language, I speak English more than Arabic, and Arabic more than Chaldean. I would say that English, which I consider [as] my second language, impacted my first language, which I would consider to be Arabic, in a negative manner. Although it was great to learn English, to do so, I had to "unlearn" Arabic, as the two languages do not directly translate.

Similarly, when Annabelle (Group 15) was asked about her opinion about mixing English and another language, she referred to her Greek identity to substantiate her answer:

I accept the mixture of English with other languages because I know how hard it is to completely learn another language. My family comes from Greece and some family members have a hard time speaking English so I have grown up around it.

From these extracts, we can see that the project was not limited to the Chinese or American cultures/languages, but rather evoked a wide array of cultural identities: Indonesia, Korean, Arabic, Chaldean, and Greek. It was unlikely that the participants had planned to present these identities before the activity. Rather, they performed these identities that emerged from the dialogic interaction with global others.

\section{Audience Design}

Audience design refers to "the ways in which users tailor their posts to the expectations of their imagined readership" (Tagg \& Seargeant, 2014, p. 162). 
Audience design strategies usually reflect participants' agency to facilitate communication by imagining the preferences of an intended audience and taking discursive actions to accommodate them. In this transnational project, it is interesting to note that content of posts and language styles were two frequent audience design strategies.

As an example of the content strategy, Kala's group (Group 12) attempted to make their adapted Chinese story ("Buy the case and return the pearl") relatable to their American peer, by starting the adaption with these engaging questions: "Have you ever been to those luxury shops, such as Tiffany \& CO. or Michael Kors? After you have purchased the jewelry, would you return the jewelry back to shop and just [keep] the box instead?" Indeed, this audience design strategy facilitated the comprehension of the Chinese story and was appreciated by the American peer:

I was able to understand the message being conveyed by merely reading the story, but by providing a summary of the story in the beginning and using modern day examples, such as Michael Kors, I was able to understand better what the story was attempting to portray. (Alan)

Another example of audience design was found in Kandy's deliberate choice of language style in her self-introduction. She described herself as a "sophomore." Then, in the middle of the interaction, when the group discussed the relation between language and culture, Kandy (Group 22) explained that her use of "sophomore" was a strategic attempt to accommodate the American peer's preferred way of expression:

Do you remember I introduced myself as a sophomore? Actually, we NEVER said this term in Hong Kong! We would just say "I am a Year 2 student." By watching YouTube videos, I understand that Hong Kong and the US have such difference in stating our four years of undergraduate education. Therefore, I used the word

"sophomore" instead to eliminate the confusion.

A combination of content and language strategies for audience design was used by Kyle (Group 1) when he tried to explain what it meant to read ancient Chinese, which had no punctuation and almost no subjects or objects in a sentence. He used texts from the Bible (a content strategy) and adapted the texts to reflect the ancient Chinese features (a language strategy):

... imagine this, omit some of the subjects or objects, connectives are not needed too, just make sure you keep the verbs. Oh by the way, help me remove all the punctuations. This is the result if this is put into English (in a rudimentary way though): 
God so loved gave only begotten Son believeth in not perish have everlasting life.

One final note about audience design is that communication difficulties led students to reflect on the importance of the strategy. For instance, Karan (Group 24) had difficulty understanding her American peer's choice of English writing-Gettysburg Address. In one of her responses, she confessed that she had "trouble digesting [the speech] and understanding the underlying meaning behind the passage" because she did "not really know about the civil war and the detailed history of America." This comprehension issue prompted her to reflect on the centrality of imagining and accommodating the readership:

Before talking with a student from another country, I should consider their cultural and education background and, hence, decide how detailed the information that I am going to give is. In this case, it would be nice if there were some explanation, such as background of the story along with the speech.

\section{Translingual Strategies}

Although English was the default language for the online exchange, some participants took initiative to enact translingual practices to elucidate their arguments or establish solidarity. For example, Kalyn (Group 2) and her American peer were discussing the "hardest part about learning another language." In Kalyn's response, she supported her claim ("learning the pronunciation of the new language is the hardest part") by comparing the pronunciation systems of English, Chinese, and French. She not only described the issue but also illustrated it with French pronunciation scripts:

English is pronounced with the alphabet, I had to learn phonics to grasp the formation of each word. While French uses a different system to pronounce, French has no diphthong which is different from English and Chinese. It has five diacritical sign to indicate a different pronunciation, like [^], [“] and ['].

In another group's interaction, when Andy (Group 17) responded to his Hong Kong peer's question about his "first impression of the Chinese language," he not only explained his feelings in the English language but also cited Chinese characters to illustrate his perceived difficulty about learning Chinese:

Another complexity I have noticed is the "儿化" that can make two different words sound very similar like how “耳” [meaning ear] and "二" [meaning two] sound like the same word to me. 
Importantly, the two previous examples show that the participants did not stick to the default language (i.e., English) but resorted to other languages to substantiate their arguments.

Translingual strategies were also deployed by the participants to create solidarity. For instance, when Kate responded to her American peer's travel essay, she used Japanese, Thai, and Vietnamese to show that she also had some experience as a cultural tourist:

I admire you have seen much of the world with traveling around different countries and cities. I have been [to] a few countries in Asia such as Japan, Vietnam, and Thailand. But I can't even name any of word in their language except basic greetings likeこんにちは, , Xin chào and คุณเป็นยังไงบ้าง (say hi).

These examples demonstrate that the participants draw upon multiple languages that they might not be proficient in but had personal, meaningful encounters with in their daily life. This form of "banal cosmopolitanism" (Beck, 2006) was evoked by the translingual practices.

\section{Unsettling Essentialism}

One of the most common risks of transnational interaction is to formulate or enhance essentialist views about cultures and cultural preferences because of limited exposure and overgeneralization $(\mathrm{Wu}, 2018 \mathrm{a})$. CCC requires the participants to unsettle essentialist views and develop more nuanced and fluid understandings about cultures. In the interaction, there were ample opportunities for the participants to negotiate and interrogate essentialism. The first example transpired when a Hong Kong student asked Alan, "What is the most special culture in the United States in your point of view?" This was a natural question for someone living outside the United States, because one tends to wonder about the defining features different from those in one's familiar context. However, Alan aptly dismissed the notion of "the most special culture," replying,

In my opinion, the United States does not have one particular culture. In the United States millions of people from all around of the world, meaning there are millions of people with different cultures, which makes the United States not to have one particular culture.

A second example was found in Katerina's interaction with Andrew (Group 18). After reading the adapted Chinese story ("An old man losing his horse: blessing or bane?"), Andrew commented that,

There are very few writing styles like this in America ... The only pieces like this that I can think of would be TV shows or kids' books, that are simple like this but with a strong message and in America a moral or idea is rarely expressed in a short and NOT childish way 
like the reading you sent me. Your reading is unique in modern American literature.

Andrew's observation seemed to put Chinese stories in neat boxes: "short," "simple," and even perhaps "childish." To interrogate this totalizing view of Chinese writing styles, Katerina explained that,

We seldom use the style of our story in [writing] Chinese [stories].

The reading we chose to post is a story behind an idiom or a proverb so we describe it in a simple way. In Chinese, there are also many complicated and indirect articles and writing styles like you posted before.

As a third example, Keli and Amber (Group 22) were sharing their thoughts about parenthood in relation to the Chinese cultural concept of "raising a child so that he/she will look after you at an old age." Keli observed that, "the love from the Western parents is unconditional, since most of them ask nothing in return even when the children grow up." Amber concurred, "Especially in my area, our parents will give everything they can to their kids and never expect anything from them." Keli then enquired, "Is it reasonable if your parents ask you to do part time jobs and save money for buying your own car or any other things that you want?" In response, Amber unsettled the view of American parenthood as one generalizable entity:

Some more than others. Working while still in school is about 50/50; meaning it's about equal. Some Americans will begin working when they turn 18 as it is the legal working age without restrictions. But, in the area I grew up in, almost no teens work while in school (high school OR university). Our parents give us an allowance for spending money and provide us with cars, clothes, etc. So I would say the answer varies based on the region.

As shown in these three examples, the conversation often involved the interlocutor's understanding and/or imagination of the global other's tradition, which was followed by the global other's correction or revision. In this way, the conversation often went beyond the essentialist discussions of different traditions so that a more realistic and in-depth transnational communication had been achieved. The examples also show that it is natural for participants in transnational encounters to essentialize the perceived differences as static nation-based cultural traits. Therefore, participants need to be aware of their cultural assumptions and stand ready to negotiate and negate such essentialist views as "one country having one culture" and "one culture having one style." 


\section{Cosmopolitan Knowledge: Epistemic Understanding}

\section{Seeking Universals}

As explained earlier, cosmopolitanism is an ongoing quest for universalism, which requires people to seek common ground. In the interaction, there were many instances where the participants bridged seemingly unrelated concepts and attempted to seek universals. For instance, Austin (Group 17) chose a song called Stairway to Heaven as the reading piece for the Hong Kong peers "because of the poetic language and descriptions used." Apparently, the song was intended by Austin to be read aesthetically. In her response, Kerry first addressed the aesthetic aspect by appreciating the word play and then took initiative to associate the lyrics with Taoism, which could be interpreted as an effort to seek a philosophical common ground:

the words "When all are one and one is all" is like the thought of Taoism. Zhuangzi and Laozi, who are the philosophers of Taoism, explained that the essences of human beings and nature are connected. Everything follows the natural rules, and thus there is peace of mind, as well as people can tolerate everything. Consequently, the harmony between them is achieved.

By the same token, many American participants made the connections between the moral messages embedded in the ancient Chinese stories and American societal and cultural norms. For example, Adam (Group 6) read a story about Mencius's mother moving to three different places to make sure that Mencius would grow up in a good environment. Adam then commented that parents, East or West, would want the best for their children:

I enjoyed your Chinese story ... I think the story is very applicable to families in the US because the main idea was how parents try to raise their kids to the best of their ability. Parents will often suffer and make changes for the benefit of their children's future ... Western culture has, more or less, the same ideals where parents want their kids to grow up in a good environment and want them to succeed for themselves.

In the third example, Karan was asked the extent to which Chinese values represented by filial piety and Confucianism were similar to American values. She replied that desirable qualities of a person were universal and could be underpinned by the five virtues in Confucianism:

I believed that some things that are right are quite universal, such as, the 5 virtues of Confucius, benevolence (Ren), honesty (Yi), knowledge (Zhi), integrity (Xin), politeness (Li), are inevitably the qualities that both American and Chinese seek for in a person. By achieving 
these 5 virtues [advocated] by Confucius, a person can be kind to his family, friends and himself.

As demonstrated in these examples, despite apparent differences, the participants sought out philosophies, values, and qualities that are common aspirations of humanity. They exercised their agency to go beyond the particular and develop cosmopolitan knowledge in their encounters with global others.

\section{Engagement with Particularism}

Transnational projects usually aim to know more about the other cultures, with an outward gaze. However, from a cosmopolitan perspective, the encounter is never disengaged from the local particulars. An outward gaze, by its nature, can inform an inward examination. In our project, many participants remarked that the exchange with transnational peers prompted them to develop more sophisticated understanding about their own cultures. For the Hong Kong students, as they were required to adapt an ancient Chinese story for their American peers, they could not simply translate the story from Chinese to English. To increase the readability, they needed to provide more information to contextualize culturally loaded terms. This adaption process required deep engagement with their cultural particulars. As described by Khloe (Group 23),

Having so [many] Chinese expressions, especially the idioms and [references to] Chinese history books ... I also spent lots of time in searching their official names. Yet, this is a rewarding experience for us to know the differences ... between these two languages, like a lot of extra background information [is] required when describing a Chinese culture in English.

Her group member, Kira, concurred: "I agree with [Khloe] completely about our challenges when translating that piece from Chinese to English. It is so true about the proper names as they were all from ancient time so we really spent a bit [of] time digging the information!"

For the American students, the discussion with Hong Kong students about issues of language contact and interference prompted them to examine their language practices in the United States. In a telling instance, the Hong Kong students explained to Asher (Group 21) that "Chinglish usually simplified the correct grammar or shorten sentence structure to achieve efficiency" (Koran). Based on this comment, Asher wrote an elaborate response to reflect on American students' language practices and articulate his intention to write about slang terms and abbreviations in different American cultures, as signs of deeper engagement with his own linguaculture:

In response to the idea of "Chinglish" ... [it] is very similar to what we already do with our own language. When talking with friends it is very uncommon for me to use proper grammar and use exact 
English. I usually use many slang words in my daily conversation to shorten how I speak and express ideas faster and more efficiently. A funny example of this would be the word "Yain't". It means (you all are not) and combines the abbreviations " $y$ 'all" (you all) and "ain't" (are not).... I believe this is the same concept as Chinglish except you are abbreviating the English language in ways that are more similar to Chinese ... Your idea of Chinglish has also given me the idea to write about the similarities and differences of slang terms in our different cultures and how we abbreviate things differently.

\section{Discussion}

In this section, we discuss how the transnational activity contributes to learners' CCC by mapping two defining words communicative and cosmopolitan onto four dialectical relations: historicity-modernity, text-context, self-other, and universality-particularity. The four dialectical relations can provide a set of heuristics to reframe digital ELT practices from the perspective of cosmopolitanism.

\section{Communicative}

Coccetta (2018), citing Hymes's (1972) view of communicative competence, highlights the importance of rules of use vis-à-vis rules of grammar:

[I]n Hymes' (1972) view, "there are rules of use without which the rules of grammar would be useless" (p. 278). In other words, to be able to communicate effectively in a language, speakers need to have grammatical knowledge as well as the knowledge of how the members of a speech community use their language to enact social roles and reach some communicative goals. (Coccetta, 2018, p. 21; emphasis added)

This extract is meaningful for us to understand the scope of digital ELT practices. If we only focus on the rules of grammar, digital ELT practices will be limited to technology-mediated manipulation of language forms, such as using Grammarly to correct a writing assignment. If we view the rules of use as part and parcel of digital ELT practices, we should leverage networking technologies to create opportunities for learners to communicate with a cosmopolitan audience and, thus, develop their communicative repertoires.

Our pedagogical activity set an objective and a challenge for the participants to explore the rules of use through communication with peers from unfamiliar, diverse backgrounds. Kapoyannis (2019) used culturally relevant texts as an anchor to connect literacy tasks in a multicultural learning space. In our study, the participants were asked to choose seemingly culturally irrelevant texts (in terms of temporal and contextual proximities) and made them relevant for their transnational peers. To make the communication possible, 
the students must deal with two dialectical relations: historicity-modernity and text-context. For instance, the Hong Kong students were asked to select ancient Chinese texts to be read by students in a contemporary American society. The temporal and contextual traversals were replete with communication obstacles. They could not simply translate the text from Chinese to English, as the translation would trap the communication within the confines of historicity and text. Many proper names and cultural terms were relevant to an ancient Chinese society but much less so to a contemporary American student. Therefore, they needed to modernize and contextualize the ancient Chinese piece from an American student's perspective. As reported in the subsection Audience Design, some Hong Kong students strategically opened their adapted story with household brand names in America (e.g., Tiffany \& CO. and Michael Kors). This audience design strategy was deemed effective by the American student because the Hong Kong students mobilized their knowledge of the target community to address the dialectics of historicity-modernity and text-context. A less successful example was perhaps the presentation of Gettysburg Address as the text to be read by the Hong Kong students. The American student did not provide historical background about the speech and caused confusion (see Karan's extract in the subsection Audience Design). In this case, the text was not adequately contextualized to preempt communication issues for a contemporary readership unfamiliar with American history. The juxtaposition of the two cases points to the benefits of challenging learners to move texts across time scales and contexts, with a view to developing their abilities to adapt to a diverse audience.

\section{Cosmopolitan}

As argued earlier, ELT is inherently a site for cosmopolitan encounters in this increasingly networked and interdependent world. ELT practitioners should encourage learners to think outside the neat boxes of nation-based cultures and address another two dialectical relations: self-other and universalityparticularity.

In common with previous studies (e.g., Kitade, 2012; Wu, 2018b), the transnational interaction in this project could not be scripted by the predefined roles or preconceived identities of the participants. Instead, the participants drew upon their diverse backgrounds and performed their identities in response to their peers' questions about sports, music, food, and travels. In this way, the self-other dynamics are embedded in the "banal cosmopolitanism"--integrating global mass-products into their everyday lives (Beck, 2006). Kwan is a case in point. She was a Malaysian student studying in Hong Kong. She loved badminton, the national sport in Malaysia, and listened to Chinese, English, and Koran music. She also watched blockbuster English movies in Malaysia, but not in Hong Kong because of the exorbitant price. Clearly, Kwan and many other Hong Kong students in the project 
lived a cosmopolitan life, integrating global otherness into their selfhood. However, the selfhood became otherness for the American students and required the participants to reflect on their prior and present encounters with global others, thereby "transcending Self and Other and bringing into play the transformative and self-reflexive moment" (Delanty, 2009, p. 14).

Hawkins (2018), paraphrasing Agar (1994), contends that "things are not visible until they bump up against something unfamiliar" (p. 72). When the self and the other meet, they would see and notice things that are unfamiliar to them. That was why the participants asked questions about cultural traits and writing styles, as attempts to understand the unfamiliar. Framed from the universality-particularity perspective, they were trying to figure out whether the unfamiliar was particular to the other. At this point, if the participants did not critically reflect on the questions they asked and the underlying assumptions projected, the interaction might ironically lead to reinforcement of cultural stereotypes (Helm, 2015). As reported in previous studies (e.g., You, 2016) and corroborated by the current one, sometimes, the students formed essentialist views and presented them uncritically (see the extracts in the subsection Unsettling Essentialism). Therefore, ELT practitioners need to remind the participants to uphold the dispositions of openness and inquiry, instead of jumping to conclusions in the transnational encounters.

Extending the contention of Hawkins (2018) and Agar (1994), we argue that things are more visible if they bump up against something familiar in global others. This means that the encounters with global others can bring out the universality from the particular. For instance, Kate used four languages (i.e., English, Japanese, Vietnamese, and Thai) to show that she had been to several Asian countries and picked up some greetings in the local languages. Kate's translingual practice was prompted by Andrea's piece about a travel bug with lots of cultural and language experiences. Kate commented that "I think we are the same type of people. I love traveling while having a lot of passion on learning a new language." Then, Andrea reciprocated, "I do love traveling and would love to eventually learn another language. And yes, I also think we are the same type of person!" This episode and many similar others show that the participants reinforced their self-understanding as a result of bonding with a like-minded global other. The individual particulars became social universals, thus, forging cosmopolitan connection beyond national borders. As such, transnational activities have great potential to enable students to "perceive human connectedness as being deeply underpinned in the various accents, styles, and uses of language in everyday life and literary culture" (You, 2016, p. 6).

A final note is a meaningful chain of dialectical pursuit: self-other-universal-particular, which represents an ideal scenario of digital ELT practices. When the participants engaged in self-other dialogic interaction, they noticed and picked up something universal. However, they did not stop the intellectual pursuit but rather had a deeper engagement with the particular. This is 
best illustrated in Asher's interaction. Koran explained to Asher that Chinglish was frequently used among her Chinese peers because the nonstandard, shortened forms achieved communication efficiency. Asher then took note of the similarity in that her friends rarely "use proper grammar and use exact English" in conversation. The perceived universal principle of communication efficiency over standard grammar led Asher to reflect on the use of the abbreviated forms, such as "Yain't," "y'all," and "ain't." She also compared the abbreviated forms in English with those in Chinglish: "I believe this is the same concept as Chinglish except you are abbreviating the English language in ways that are more similar to Chinese." In sum, the self-other relation encourages the participants to set a cosmopolitan reference frame to draw out the common features beyond the artificial confines (e.g., nation-state, ethnicity, etc.). Then, the perceived or imagined universality prompts the participants to reflect on their local particulars and compare them with the particulars in other locales. These intellectual endeavours (dialogic, inductive, deductive, and comparative) all contribute to the pursuit of "universalism plus difference," the defining feature of cosmopolitanism (Appiah, 2005)

\section{Conclusion and Implications}

The fluid nature of a virtual third space affords resources and opportunities for language learners to develop their CCC and concomitantly a "liminal persona" (Wilkinson, 2012) — those who are able to "mediate differences, absorb contradictions into themselves, draw away the dangers of in-betweenness" (Morehouse, 2004, p. 31). In this article, we adapt Byram's $(1997,2008)$ ICC framework and propose the notion of CCC, highlighting the acquisition of cultural knowledge and communication skills as a dynamic, emergent process. To illustrate how CCC can guide the design of pedagogical activities that tap into linguistic/cultural diversities, we map CCC onto four dialectical relations: historicity-modernity, text-context, self-other, and universalityparticularity. We suggest using texts with historical and contextual constraints as the point of departure for online transnational encounters. Then, participants are challenged to adapt, transform, and interpret the texts by drawing on multiple meaning-making resources to communicate cultural meanings to the global others. In the ensuing online discussion, they are guided to place the texts in the temporal and contextual perspectives and relativize the embedded cultural knowledge in a global frame. The relativization of the self in light of the other can enable learners to communicate across differences or transcend "beyond diversity to a common normative world" (Delenty, 2009, p. 253). In the meantime, participants should be aware that the universality is never a static end state but an ongoing pursuit that parallels with a constant engagement with the particular. The recursive reflective cycles between the self and the other, the universality and the particularity, 
become a powerful source to enhance learners' CCC. As Kramsch (2014) aptly pointed out, for the contemporary language learners, "developing their own voice increasingly means developing an ear for the voices of others" (p. 309). We believe that CCC is pertinent to sensitizing language learners to different voices and harmonizing these voices through dialogic, reflective interactions. Hopefully, our pedagogical activity and the four underlying dialectical relations have provided a set of heuristics for ELT practitioners to design online transnational projects to engage learners in be(com)ing cosmopolitan communicators in the super-diverse world.

\section{Acknowledgement}

We would like to thank the anonymous reviewers for their constructive comments on an earlier draft of the article.

\section{The Authors}

Zhiwei $\mathrm{Wu}, \mathrm{PhD}$, is an assistant professor at Hong Kong Polytechnic University. Since 2009, he has been an organizer and coordinator for a transnational English writing project, engaging university students in online intercultural exchange. His research interests include multiliteracies, English for specific purposes, and translation studies.

Xinqiang $\mathrm{Li}, \mathrm{PhD}$, is an assistant professor in the Department of Writing, Rhetoric and American Cultures at Michigan State University. His research interests include intercultural rhetoric, studies in prose style, second language writing, and curriculum design. He has conducted different comparative studies between Chinese and English writing and relevant transnational writing projects.

\section{References}

Agar, M. (1994). Language shock: Understanding the culture of conversation. New York: William Morrow.

Appiah, K. A. (2005). The ethics of identity. Princeton: Princeton University Press.

Baralt, M. (2012). Coding qualitative data. In A. Mackey \& S. Gass (Eds.), Research methods in second language acquisition: A practical guide (pp. 222-244). Wiley-Blackwell.

Beck, U. (2006). Cosmopolitan vision. Cambridge: Polity.

Belz, J., \& Vyatkina, N. (2005). Learner corpus analysis and the development of L2 pragmatic competence in networked inter-cultural language study: The case of German modal particles. Canadian Modern Language Review, 62(1), 17-48. https:/doi.org/10.3138/cmlr.62.1.17

Byram, M. (1997). Teaching and assessing intercultural communicative competence. Clevedon: Multilingual Matters.

Byram, M. (2008). From foreign language education to education for intercultural citizenship: Essays and reflections. Clevedon: Multilingual Matters.

Byram, M. (2012). Conceptualizing intercultural (communicative) competence and intercultural citizenship. In J. Jackson (Ed.), The Routledge handbook of language and intercultural communication (pp. 85-97). London: Routledge.

Canagarajah, S. (2018). Transnationalism and translingualism: How they are connected. In X. You (Ed.), Transnational writing education: Theory, history and practice (pp. 41-60). New York and London: Routledge.

Coccetta, F. (2018). Developing university students' multimodal communicative competence: Field research into multimodal text studies in English. System, 77, 19-27. https://doi. org/10.1016/j.system.2018.01.004

Connor, U. M., Davis, K. W., De Rycker, T., Phillips, E. M., \& Verckens, J. P. (1997). An interna- 
tional course in international business writing: Belgium, Finland, the United States. Business Communication Quarterly, 60(4), 63-74. https://doi.org/10.1177/108056999706000404

Council of Europe. (2018). Common European framework of reference for languages: Learning, teaching, assessment. Companion volume with new descriptors.

Delanty, G. (2009). The cosmopolitan imagination: The renewal of critical social theory. Cambridge: Cambridge University Press.

Edasawa, Y., \& Kabata, K. (2007). An ethnographic study of a keypal project: Learning a foreign language through bilingual communication. Computer Assisted Language Learning, 20(3), 189-207. https://doi.org/10.1080/09588220701489473

Friedman, D. (2012). How to collect and analyze qualitative data. In A. Mackey \& S. Gass (Eds.), Research methods in second language acquisition: A practical guide (pp. 180-200). Wiley-Blackwell.

Galante, A. (2014). Developing EAL learners' intercultural sensitivity through a digital literacy project. TESL Canada Journal, 32(1), 53-66. https://doi.org/10.18806/tesl.v32i1.1199

Hawkins, M. R. (2018). Transmodalities and transnational encounters: Fostering critical cosmopolitan relations. Applied Linguistics, 39(1), 55-77. https://doi.org/10.1093/applin/amx048

Helm, F. (2015). The practices and challenges of telecollaboration in higher education in Europe. Language Learning \& Technology, 19(2), 197-217. https://doi.org/10125/44424

Hymes, D. H. (1972). On communicative competence. In J. B. Pride \& J. Holmes (Eds.), Sociolinguistics: Selected readings (pp. 269-293). Harmondsworth, England: Penguin.

Kapoyannis, T. (2019). Literacy engagement in multilingual and multicultural learning spaces. TESL Canada Journal, 36(2), 1-25. https://doi.org/10.18806/tesl.v36i2.1298

Kitade, K. (2012). An exchange structure analysis of the development of online intercultural activity. Computer Assisted Language Learning, 25(1), 65-86. https://doi.org/10.1080/0958822 1.2011 .584512

Kostogriz, A. (2005). Dialogical imagination of (inter)cultural spaces: Rethinking the semiotic ecology of second language and literacy learning. In J. K. Hall, G. Vitanova, \& L. Marchenkova (Eds.), Dialogue with Bakhtin on second and foreign language learning (pp. 189-210). Mahwah, NJ: Lawrence Erlbaum.

Kramsch, C. (2014). Teaching foreign languages in an era of globalization: Introduction. The Modern Language Journal, 98(1), 296-311. https://doi.org/10.1111/j.1540-4781.2014.12057.x

Kramsch, C., \& Kramsch, O. (2000). The avatars of literature in language study. The Modern Language Journal, 84(4), 553-573. https://doi.org/10.1111/0026-7902.00087

Mackey, A., \& Gass, S. M. (2005). Second language research: Methodology and design. Mahwah, NJ: Lawrence Erlbaum.

Mihelj, S., Van Zoonen, L., \& Vis, F. (2011). Cosmopolitan communication online: YouTube responses to the anti-Islam film Fitna. The British Journal of Sociology, 62(4), 613-632. https:// doi.org/10.1111/j.1468-4446.2011.01383.x

MLA Ad Hoc Committee on Foreign Languages. (2007). Foreign languages and higher education, new structures for a changed world. Profession, 234-245. https://doi.org/10.1632/ prof.2007.2007.1.234

Morehouse, B. (2004). Theoretical approaches to border spaces and identities. In V. PavlakovichKochi, B. Morehouse, \& D. Wastl-Walter (Eds.), Challenged borderlands: Transcending political and cultural boundaries (pp. 19-39). Aldershot: Ashgate.

Richards, K. (2003). Qualitative inquiry in TESOL. New York, NY: Palgrave Macmillan.

Risager, K. (2007). Language and culture pedagogy: From a national to a transnational paradigm. Clevedon: Multilingual Matters.

Ros i Solé, C. (2013). Cosmopolitan speakers and their cultural cartographies. The Language Learning Journal, 41(3), 326-339. https://doi.org/10.1080/09571736.2013.836349

Street, B. V. (1993). Culture is a verb: Anthropological aspects of language and cultural process. In D. Graddol \& M. Byram (Eds.), Language and culture (pp. 23-43). Clevedon, England: BAAL in association with Multilingual Matters. 
Tagg, C., \& Seargeant, P. (2014). Audience design and language choice in the construction and maintenance of translocal communities on social network sites. In P. Seargeant \& C. Tagg (Eds.), The language of social media (pp. 161-185). New York: Palgrave Macmillan.

UNESCO. (2014). Global citizenship education: Preparing learners for the challenges of the twenty-first century. United Nations Educational, Scientific, Education Sector. Paris.

Vertovec, S. (2007). Super-diversity and its implications. Ethnic and Racial Studies, 30(6), 10241054. https://doi.org/10.1080/01419870701599465

Walsh-Marr, J. (2011). Keeping up the conversation on culture: A response to Robert Courchêne and others. TESL Canada Journal, 29(1), 113-120. https://doi.org/10.18806/tesl.v29i1.1093

Wilkinson, J. (2012). The intercultural speaker and the acquisition of intercultural/global competence. In J. Jackson (Ed.), The Routledge handbook of language and intercultural communication (pp. 296-309). London: Routledge.

$\mathrm{Wu}, \mathrm{Z}$. (2018a). Technology-mediated transnational writing education: An overview of research and practice. In X. You (Ed.), Transnational writing education: Theory, history, and practice (pp. 170-186). New York: Routledge.

$\mathrm{Wu}, \mathrm{Z}$. (2018b). Positioning (mis)aligned: The (un)making of intercultural asynchronous computer-mediated communication. Language Learning $\mathcal{E}$ Technology, 22(2), 75-94. https://doi. org $/ 10125 / 44637$

You, X. (2016). Cosmopolitan English and transliteracy. Carbondale: Southern Illinois University Press.

\section{Appendix}

\section{Prompts Provided for the Hong Kong Students}

During the interaction, you may discuss the following issues (or the issues of your interest) with the American student:

- perceptions about English adaptation;

- effectiveness of communicating a Chinese cultural concept in English;

- $\quad$ interaction between culture, language, and rhetoric;

- preferred styles of Chinese and English.

\section{Prompts Provided for the American Students}

1. Briefly respond to Hong Kong students' comments and answer their questions.

2. Share the reasons why you choose your reading.

3. Your discussion questions may include:

- How do you compare Chinese and English writing generally?

- What are your favorite English essays and writing styles? Why do you like them?

- How does culture shape our language and writing?

- Issues on English in a global context. 